\title{
Forest carbon projects in the Ukrainian Carpathians: an assessment of potential community impacts and benefits
}

\author{
A.R. Egan, W.S. Keeton, C.M. Danks, I. Soloviy, A. Zia
}

Egan A.R., Keeton W.S., Danks C.M., Soloviy I., Zia A. 2017. Forest carbon projects in the Ukrainian Carpathians: an assessment of potential community impacts and benefits. Ann. For. Res. 60(1): 3-17.

Abstract. Reducing emissions from deforestation and degradation (REDD+) is a frequently promoted climate change mitigation strategy. As forest carbon projects proceed, we are learning how they affect local sovereignty and resource access, particularly in developing economies. Central and Eastern Europe's temperate forests offer potential for projects, yet little is known about how the sociopolitical context of these transitional economies may influence project success. In this article, we enhance understanding of potential community impacts and explore opportunities for fair benefit distribution in Ukraine's Carpathian Mountain region. Through a thematic qualitative and interpretive analysis of interviews and observational data, we: (1) describe what community-level forest uses and tenure rights may be affected by forest carbon projects; and (2) explore the opportunities and obstacles of fair benefit distribution and community engagement in projects in the region. Our data show that local communities in the region are important forest-dependent stakeholders, relying on the forest for fuelwood, non-timber forest products, recreation, and other intangible benefits. This indicates the need for strong social safeguards in developing forest carbon projects. While no mechanisms exist for direct revenue sharing, communities could derive other benefits that improve the local social, economic, and ecological situation. Our results further suggest that lessons from projects in developing economies can be informative to project development in post-socialist, transitioning economies.

Keywords community participation, conservation, equity, livelihoods, markets, policy, REDD+, Ukraine

Authors. Amanda R. Egan, William S. Keeton (william.keeton@uvm.edu), Cecilia M. Danks, Asim Zia - Gund Institute for Ecological Economics, University of Vermont, Burlington, VT 05405, United States; Ihor Soloviy - Institute of Ecological Economics, Ukrainian National Forestry University, Gen. Chuprynka str. 103, 79057 Lviv, Ukraine.

Manuscript received July 13, 2016; revised December 12, 2016; accepted December 19, 2016; online first January 19, 2017. 


\section{Introduction}

Emphasis on reducing emissions from deforestation and degradation (REDD + ) in the post-Kyoto climate policy regime demonstrates the importance of the agriculture, forestry, and other land uses sector in global climate change mitigation efforts (Olander, Galik $\&$ Kissinger 2012). Forest carbon projects under the voluntary carbon market and the Kyoto Protocol's flexible mechanisms (Clean Development Mechanism and Joint Implementation) can help defray the costs of forest conservation and protection by paying for carbon sequestration and storage. Projects typically focus on afforestation/reforestation, avoided deforestation and degradation, or improved forest management. While the primary goal of forest carbon projects is to reduce carbon dioxide emissions while increasing sequestration and storage, there are potentially many co-benefits, such as biodiversity enhancement, watershed protection, trans-boundary cooperation, and community development. Methodologies and protocol for carbon project development are well established internationally under both compliance and voluntary market systems (Kerchner \& Keeton 2015, VCS 2016), and demand for emissions offset credits remains robust (Hamrick \& Goldstein 2016).

Integrating local communities into conservation projects can improve attainment of conservation and climate mitigation goals, as well as social objectives (Gibson et al. 2005, Bray et al. 2008). Conversely, ineffective community participation can impede the successful fusion of these goals (Asquith et al. 2002, Zbinden \& Lee 2005). Conservation projects restricting access to lands or forests useful for livelihoods can result in negative impacts on local communities (Asquith et al. 2002, Brown \& Corbera 2003). Overlapping rights and competing claims to ownership are often encountered in developing and post-socialist countries (Corbera \& Brown 2010), and may result in the most visible and vocal stakehold- ers obtaining greater benefits (Smith \& Scherr 2003). Stakeholder perceptions of inequitable cost and benefit distribution can pose obstacles to implementation, affect long-term project sustainability, and exacerbate social inequalities (Pagiola et al. 2002, Rodríguez de Francisco et al. 2013). Concern over carbon project impacts on local sovereignty and resource access has stimulated the development of social and environmental standards (Kollmuss et al. 2008), which offer guidelines to engage local stakeholders so that costs and benefits are shared equitably and community well-being is enhanced.

While the number of forest carbon projects is increasing in North America with the recent establishment of a compliance market, projects based in tropical forests have historically been the most in demand and have transacted the highest volume of forest carbon offsets (Goldstein \& Gonzalez 2014). Although often overlooked, there is potential for forest carbon projects in the temperate forests of Central and Eastern Europe, particularly in areas where forest cover is recovering from past land uses (Kuemmerle et al. 2009, Kuemmerle et al. 2011). Many of these countries are post-socialist, transitional economies, still undergoing or recently emerged from economic liberalization and privatization. This geographical and sociopolitical context has yet to be examined in carbon project research, yet poses serious challenges for project development due, in some cases, to weak governing institutions, economic corruption, political instability, and lack of public participation in forest management decisions.

Using the case of the Ukrainian Carpathians, this article aims to contribute to the understanding of community impacts and participation in forest carbon projects. Through a thematic qualitative and interpretive analysis of interviews and observational data, we: (1) describe what forest uses and tenure rights may be affected by forest carbon projects for community members in the Ukrainian Carpathians; and (2) explore the opportunities and obstacles 
of fair benefit distribution and community engagement in projects in the region. Such an understanding will be critical to the development of equitable and sustainable forest carbon projects in the area, and may provide lessons for other post-socialist, transitional economies.

\section{Ukraine's Potential}

Ukraine is eligible to participate in Joint Implementation projects and the voluntary carbon market. While there is potential for forest carbon projects in Ukraine, no projects have been implemented as of 2015. A reforestation project on 4,352.7 hectares (ha) of land contaminated by the 1986 Chernobyl nuclear accident in northern Ukraine was developed as a Joint Implementation Agreement under the Kyoto Framework in partnership with the World Bank BioCarbon Fund. The project was cancelled for a variety of reasons, including contractual disputes, problems transferring lands, and high initial investment (Sergiy Zibtsev, discussion with author, February 25, 2012). While this early experience indicates challenges for project development and implementation, interest in forest carbon projects remains, particularly in the Carpathian region. The Carpathian Mountain range is Europe's second longest mountain range, approximately $1,500 \mathrm{~km}$ long and spanning seven countries. The mountains run northwest to southeast through western Ukraine, a region with over $40 \%$ forest cover that accounts for $20 \%$ of total national forested area (Nordberg 2007). The Carpathian region contains high conservation value forests, including the largest remaining stands of old growth Fagus sylvatica, over 200 endemic plant species, and a full complement of large European mammals. The region's temperate forests consist of hardwood, coniferous, and mixed hardwood-conifer types.

\section{Sociopolitical context}

Western Ukraine has a political history defined by competition among regional powers, periods of pronounced socioeconomic turmoil and deprivation, and simmering nationalist identities. Northwestern Ukraine fell under Polish rule following World War I and was later annexed by the Soviet Union in 1939. Nazi Germany's invasion of the USSR in 1941 led to a brutal period of occupation until the Germans were expelled in 1944. Meanwhile, southwestern Ukraine passed between Hungary and Czechoslovakia before becoming part of the Ukrainian Soviet Socialist Republic in 1946. Once part of the Soviet Union, private land was expropriated and collectivized, and forestry became more intensive with harvest rates peaking in the 1950s (Kuemmerle et al. 2011). This history contributes to a mix of ethnic and cultural backgrounds in the region. Since independence in 1991, Ukraine has struggled to develop a free market economy, reform political institutions, and define a cohesive national identify. At time of writing, the country is riven by separatist conflict in eastern Ukraine and Russian military intervention.

\section{Forest management challenges}

There are a number of challenges facing sustainable forest management in the Carpathian region, including illegal timber harvesting, poorly designed forest road systems, inadequate investment in the forest sector, and inconsistently applied watershed and riparian protections (Keeton et al. 2013). Even-aged management with clearcutting is predominant, particularly in spruce forests (Strochinskii, Pozyvailo \& Jungst 2001). Dieback of spruce plantations, a legacy dating to the Austro-Hungarian era of planting genetically non-endemic varieties of $P$. abies that has led to increased vulnerability and is exacerbated by compounded stresses, is often followed by salvage logging ("sanitary cutting") and occasionally is restored to endemic species composition (Irland \& Kremenetska 2009). Selection systems are often used in beech forests and there 
is innovation with an even to uneven-aged conversion system based on group selection, called "close-to-nature" silviculture (Keeton et al. 2013). Ukraine's state forestry enterprises (SFEs) have historically conducted and administered all aspects of timber harvesting operations. Private sector logging and transportation markets are beginning to develop (Nordberg 2007, Soloviy \& Cubbage 2007), a transitional process illustrative of economies undergoing economic liberalization. Because there is little public funding available for Ukraine's forestry sector (Soloviy \& Cubbage 2007), forest carbon projects could provide investment to modernize technology and promote sustainable forest management.

Illegal harvesting is a growing concern (Kuemmerle et al. 2009) and may reflect Ukraine's relatively high rate of corruption and ineffective rule of law. According to the World Bank's governance indicators, Ukraine ranks in the $23^{\text {rd }}$ percentile for rule of law and in the $12^{\text {th }}$ percentile for control of corruption (Kaufmann et al. 2014). The Corruption Perceptions Index ranks Ukraine as 142 out of 175 countries with a score of 26 out of 100 (Transparency International 2014). While carbon projects could help protect forests from illegal harvesting, corruption and ineffective rule of law pose obstacles to projects. Since self-reported data on corruption is difficult to obtain, we addressed possible governance and corruption concerns by collecting stakeholder perceptions of forest management and managers.

\section{Forest tenure and use}

While some Central and Eastern European countries have implemented a restitution policy for forestlands nationalized or collectivized during state socialism (Sikor 2003), Ukraine has maintained state ownership, reflecting its $20^{\text {th }}$ century history of nationalization. Forests in Ukraine are almost completely state-owned (over 95\%) and are managed primarily by SFEs within the Forest Resources Agency (formerly the State Committee of Forestry; 66.1\%), with the Ministries of Agricultural Policy, Defense, Emergencies, and Environment Protection all managing smaller portions of forestland. Administration, legislation, and management activities are all combined under the authority of the state forestry administrations (Soloviy $\&$ Cubbage 2007). The global tenure reform movement of transferring forests to community ownership and management (Larson, Barry \& Dahal 2010) is not strong in Ukraine.

Ukraine's independence in 1991 led to a period of economic turmoil marked by low output and hyperinflation. While the economy rapidly grew in the early 2000 s, the 2008 economic crisis caused a contraction in growth, which was gradually easing prior to the current conflict in eastern Ukraine. Decreased standards of living resulted in the renewed importance of traditional agricultural practices that were prevalent before socialism (Elbakidze \& Angelstam 2007). Historically, villagers in the Carpathian Mountains relied on forest resources to sustain daily life. Forests provided building materials, fuelwood, food from plants and animals, forage for cattle, and income through employment in the logging industry (Amato 1998). Increased forest clearing to accommodate agriculture and a growing demand for timber exports in the second half of the $19^{\text {th }}$ century disrupted these traditional uses, which were further impaired by escalation of the forest industry under the Soviet regime (Amato 1998, Elbakidze \& Angelstam 2007). Non-timber forest products (NTFPs) continue to support livelihoods in rural Ukraine (Stryamets et al. 2012). We add to this research by expanding the picture of contemporary community forest use, which we then use to suggest potential impacts from carbon projects. 


\section{Methods}

\section{Study area}

To understand contemporary local relationships to forests in the Ukrainian Carpathians, we focused data collection in two villages representative of the rich diversity of socioeconomic conditions and forest management (Figures 1 and 2). In selecting study sites, we used the following criteria: proximity to large forest tracts suitable for projects, diversity of forest management agencies, similar population size, and differing histories and cultural backgrounds. Henceforth the villages will be referred to as Berezivka and Stariy Kamin'

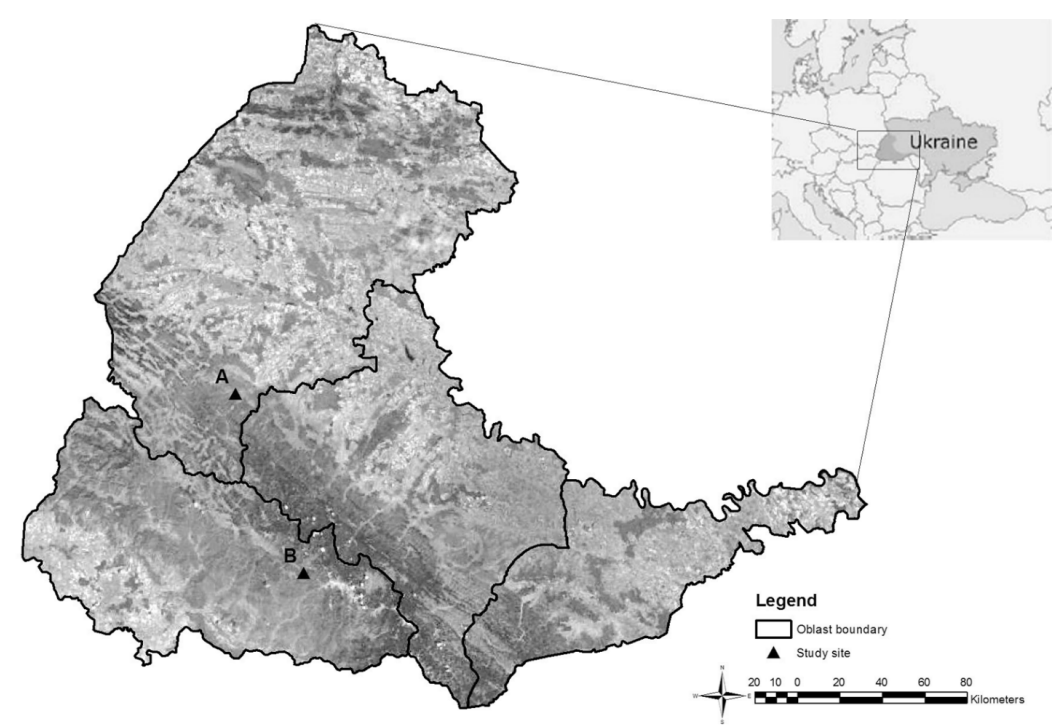

Figure 1 Locations of village study sites in the Carpathian region of Ukraine. A: Berezivka. B: Stariy Kamin'. Village names changed to protect identities. Map produced by Oleh Chaskovskyy, Ukrainian National Forestry University.

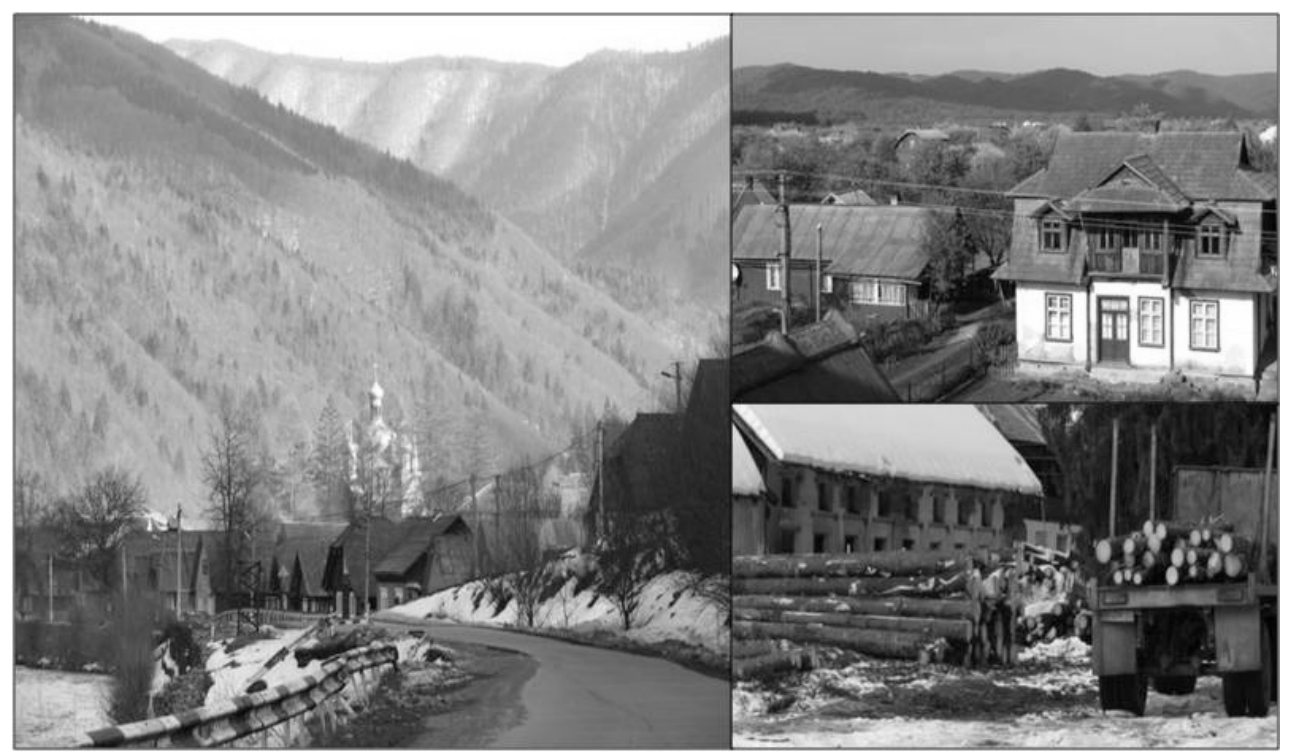

Figure 2 Carpathian villages, Ukraine. Left: Stariy Kamin'. Top right: Berezivka. Bottom right: Sawmill in Stariy Kamin' 
(names are changed to protect research participant identities).

Berezivka is located near a national nature park (24,000 ha), which includes a core reserve and recreational zones. Part of the park is held as a management zone (10,800 ha) where the local military forest enterprise (Ministry of Defense) conducts traditional forest management. The area also has forestland managed by an agricultural forest enterprise (Ministry of Agricultural Policy) and a local SFE. Berezivka's residents have easy access to urban amenities and employment opportunities outside the village. The district center (population: 6,200) is a short drive away along a regular bus route. The area is a popular recreation destination for residents of L'viv, the most populous city in the oblast (provincial region); many L'viv residents own country houses in the region's villages. Located in L'vivs'ka oblast, Berezivka (population: 1,200) lies on the northeastern side of the Carpathian Mountains at $399 \mathrm{~m}$ a.s.l. Many inhabitants of the region belong to the Boiko ethnographic group.

Stariy Kamin' is representative of a more remote village. While there are several villages nearby, the district center (population:
9,000) is less accessible than is the case in Berezivka. The adjacent forests are managed by local SFEs that practice traditional timber management. Founded in the mid-1700s under the Austrian Empire as a source of timber, the village is nestled in a narrow river valley between mountains. Much of the population has traditionally relied on forestry sector employment, primarily through the SFE or, more recently, private forest processing enterprises. An outdoor recreation center previously operated in the area, providing an alternate source of employment. Upon its closure, smaller tourist enterprises have sprung up to accommodate visitors from urban areas. Stariy Kamin' (population: 1,500) is located in Zakarpatts'ka oblast (Transcarpathia) at $530 \mathrm{~m}$ a.s.l. Many inhabitants in this region are part of the Hutsul ethnographic group.

\section{Data collection and analysis}

Data were collected through observations and interviews with potential project stakeholders and those knowledgeable about community forest use, including representatives from local communities, governmental and non-govern-

Table 1 Interview participant demographics $(n=44)$

\begin{tabular}{|c|c|c|c|c|c|c|c|c|}
\hline \multirow[b]{2}{*}{ Location } & \multicolumn{7}{|c|}{ Stakeholder group } & \multirow[b]{2}{*}{ Total } \\
\hline & $\begin{array}{l}\text { Acade- } \\
\text { mic }\end{array}$ & $\begin{array}{l}\text { Commu- } \\
\text { nity mem- } \\
\text { ber }\end{array}$ & $\begin{array}{c}\text { Private } \\
\text { forest } \\
\text { industry }\end{array}$ & $\begin{array}{l}\text { Local } \\
\text { govern- } \\
\text { ment }\end{array}$ & $\begin{array}{c}\text { Oblast } \\
\text { govern- } \\
\text { ment }\end{array}$ & $\begin{array}{l}\text { Local } \\
\text { or } \\
\text { oblast } \\
\text { NGO }\end{array}$ & $\begin{array}{c}\text { Interna- } \\
\text { tional } \\
\mathrm{NGO}\end{array}$ & \\
\hline Berezivka & 2 & 12 & 1 & 3 & 2 & 1 & 0 & 21 \\
\hline Stariy Kamin' & 2 & 12 & 1 & 2 & 1 & 2 & 0 & 20 \\
\hline $\begin{array}{l}\text { National Level } \\
\text { Key Informants }\end{array}$ & 2 & 0 & 0 & 0 & 0 & 0 & 1 & 3 \\
\hline \multirow[t]{3}{*}{ Total } & 6 & 24 & 2 & 5 & 3 & 3 & 1 & 44 \\
\hline & \multicolumn{2}{|c|}{ Gender } & & \multicolumn{5}{|c|}{ Age } \\
\hline & Male & Female & & $<18$ & $18-35$ & $36-55$ & $56-75$ & $75+$ \\
\hline Berezivka & 13 & 8 & & 0 & 5 & 12 & 3 & 1 \\
\hline Stariy Kamin' & 15 & 5 & & 0 & 5 & 11 & 4 & 0 \\
\hline $\begin{array}{l}\text { National Level } \\
\text { Key Informants }\end{array}$ & 2 & 1 & & 0 & 1 & 2 & 0 & 0 \\
\hline Total & 30 & 14 & & 0 & 11 & 25 & 7 & 1 \\
\hline
\end{tabular}


mental organizations (NGOs), and local forest industry ( $n=44$; Table 1$)$. Target numbers were established for each stakeholder group, as well as for gender and age class, to collect a diversity of perspectives. Due to a predominantly male forest sector in Ukraine, we sought to incorporate female perspectives. Accordingly, $31.82 \%$ of interviews were conducted with females, primarily in the community member and NGO categories. Participants were chosen serially, providing the opportunity to fill holes (Lincoln \& Guba 1985) and were recruited in two ways: identified by the researcher or identified by an interviewee. Participants are best understood as key informants representing perspectives of different stakeholder groups, rather than as a well-distributed population sample.

Open-ended questions focused on forest tenure and use; interactions between community members and SFE representatives; forest carbon project potential in the region (benefits, challenges); and possible revenue distribution mechanisms. The concept of forest carbon projects was described and contextualized during the interview. Interviews were semi-standardized with some questions differing by stakeholder group to focus on relevant issues. This accounts for variance in respondent numbers between questions. Interviews were conducted in Ukrainian, with the questionnaire available in Ukrainian. Interviews were later translated into English and transcribed for analysis.

Observations of daily life and the relationship between community members and forest resources were recorded in a research journal and coded with interview responses. Such observations corroborated interview responses and provided additional information not disclosed during interviews. A thematic analysis of the dataset was conducted with the ATLAS. ti qualitative analysis software. In a first round of coding, interview and observation data were inductively coded for emergent themes. Codes relevant to the research questions were aggregated in a second coding round to in- crease reliability. Literature-derived themes on market-based forest conservation schemes were then used to deductively code the data. An analysis of code co-occurrences was used to check the relevance of key themes in the interview and observational data. Second-round and literature-derived codes were grouped into thematic categories to identify research findings (Marshall \& Rossman, 2011).

\section{Results}

\section{Forest tenure and use}

Community members reported no difficulty in using the forest for recreational activities, such as walking or picnics, or collection of NTFPs. Entry into forests in Ukraine is free and protected under law, though it may be restricted during times of fire risk. A permit is required when collecting NTFPs for sale, but it was reported that this is sometimes ignored. Any cutting of trees is prohibited and subject to a fine without the authorization of a permit. When asked how often they visit the forest, 6 (of 21) community members responded always or every day, 3 responded every week or often, and 4 responded when possible. Eight community members said their frequency in the forest depends on the season, with a majority visiting often in summer and seldom in winter.

Community members reported their primary forest uses as fuelwood (23 of 24 respondents) and the collection of berries (23) and mushrooms (21). Intangible or spiritual values, medicinal plants, and recreation also ranked highly (Table 2). When asked which forest uses are the most important personally, community members responded fuelwood (10 of 20 respondents), recreation (8), mushrooms (7), and berries (6). Six community members reported receiving income from forest-related activities, such as employment with the local SFE, sale of NTFP, or tourism activities.

Fuelwood emerged as a vital forest use in 
Table 2 Primary uses of the forest and forest resources by community members. Community member interview participants were asked in what ways they personally use the forest and which forest use is the most important to them. Respondents were allowed to give multiple answers. In all interview results, unanswered and unclear responses were eliminated.

\begin{tabular}{lcc}
\hline & \multicolumn{2}{c}{ Number of respondents } \\
\cline { 2 - 3 } Forest use & Personally use & Most important \\
\hline Fuelwood & 23 & 10 \\
Berries & 23 & 6 \\
Mushrooms & 21 & 7 \\
Intangible / spiritual benefits & 17 & 2 \\
Medicinal plants / herbal tea & 14 & 0 \\
Recreation & 13 & 8 \\
Other household products / uses & 8 & 2 \\
Other food & 7 & 0 \\
Timber / processing & 6 & 1 \\
Tourism & 2 & 1 \\
Growing / protecting the forest & 1 & 1 \\
Ecosystem services & 1 & 0 \\
Health & 1 & 1 \\
Sale of NTFP & 1 & 0 \\
All uses & 0 & 1 \\
Total respondents & 24 & 20 \\
\hline
\end{tabular}

these communities. It was one of the most common forest uses and the most important among community members. Four interview participants equated fuelwood to survival in Carpathian villages: "Firewood is in first place because we cannot survive without it" (community member). Fuelwood is the sole source of heating and cooking in many villages in the region. Nine participants mentioned illegal tree harvesting by community members in interviews and observations, primarily for fuelwood, both for personal use and sale. Several community members in Stariy Kamin' mentioned that procuring fuelwood illegally, either through independent harvesting or purchase from illegal harvesters, can be faster and cheaper than purchasing fuelwood legally from the SFE.

Eight interview participants (7 community members, 1 private forest industry representative) equated the forest to life or survival during interviews. Several of these participants, all from the more remote Stariy Kamin', expressed that it is fundamentally necessary to use the forest as a resource. In the words of one Stariy Kamin' resident: "If there's going to be no forest use, we will not survive. This is the only thing that will keep us alive." No participant expressed the view that forests play an unimportant role in his or her life. When asked about their ideal scenario of forest use, 13 (of 21) respondents described situations with less logging, more sustainable forest management, or a more planned approach to forest management. Four respondents thought ideal forest management for the region would be protective management or using the forest only for fuelwood. Four respondents had other ideas, such as increased tourism or opening their own sawmill.

While the majority of interview participants would support forest carbon projects in the region (Table 3 ), 10 respondents (8 community members, 1 local government representative, 1 private forest industry representative) expressed concern about continued forest access in the case of forest protection (i.e. prohibited logging) projects. They responded they would only support a carbon project that allowed traditional forest uses and did not restrict access 
Table 3 Support for forest carbon projects in the Ukrainian Carpathian region. Interview participants $(\mathrm{n}=44)$ were asked whether they would support a forest protection project, an improved forest management project, or an afforestation/reforestation project.

\begin{tabular}{lccc}
\hline \multirow{2}{*}{ Level of support } & \multicolumn{3}{c}{ Number of respondents } \\
\cline { 2 - 4 } & $\begin{array}{c}\text { Forest } \\
\text { protection }\end{array}$ & $\begin{array}{c}\text { Improved forest } \\
\text { management }\end{array}$ & $\begin{array}{c}\text { Afforestation/ } \\
\text { Reforestation }\end{array}$ \\
\hline Support & 31 & 38 & 34 \\
Support with conditions / Maybe & 10 & 3 & 5 \\
Doesn't support & 1 & 1 & 0 \\
Doesn't know & 1 & 0 & 0 \\
Total respondents & 43 & 42 & 39 \\
\hline
\end{tabular}

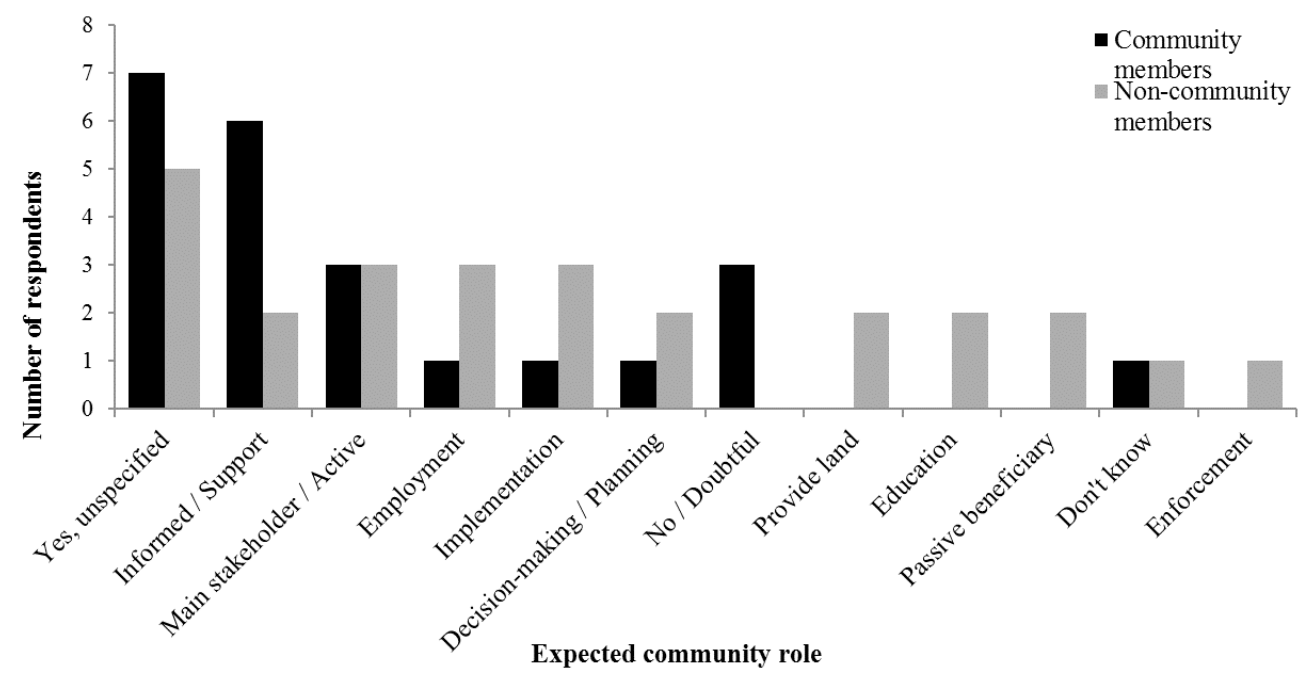

Figure 3 Role of the community in forest carbon projects. Interview participants were asked whether they saw a role for the community in forest carbon projects and to identify that role. Respondents $(n=36)$ were allowed to give multiple answers.

to forest resources necessary for their survival. In the case of forest protection projects, these respondents would prefer only part of the forestland to be classified as core reserve prohibiting entry and collection of NTFPs. Nine of 10 of these respondents were from Stariy Kamin', perhaps reflecting less direct experience with forest reserves than respondents in Berezivka, who live near a national nature park.

\section{Community participation and potential bene-}

\section{fit distribution}

Only 4 (of 23) community members reported the SFE informs the public of forest management goals, objectives, and activities, while 6 reported that the SFE provides some information, and 13 reported that the SFE does not inform the public. When asked their perspectives on the role community members could play in carbon projects, 12 (of 43) responded communities could play a role, but did not explain the role further (Figure 3). Other respondents sug- 


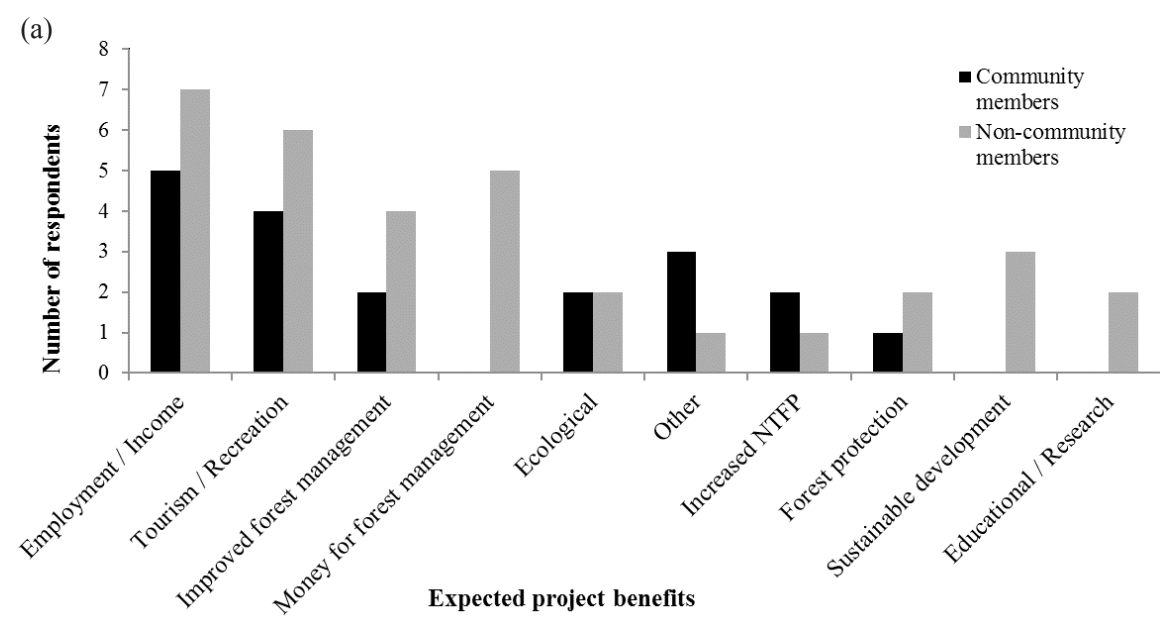

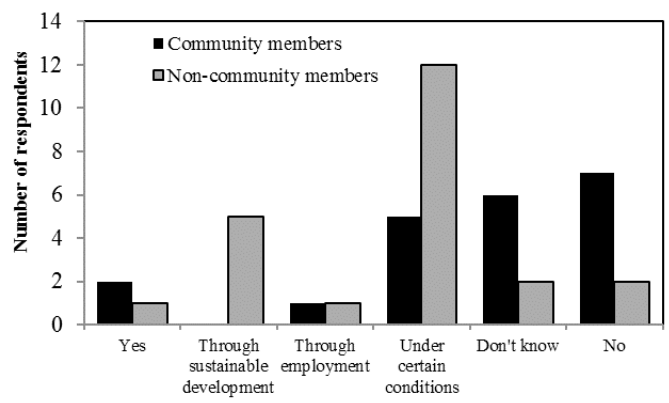

(b)

Community shares project revenue

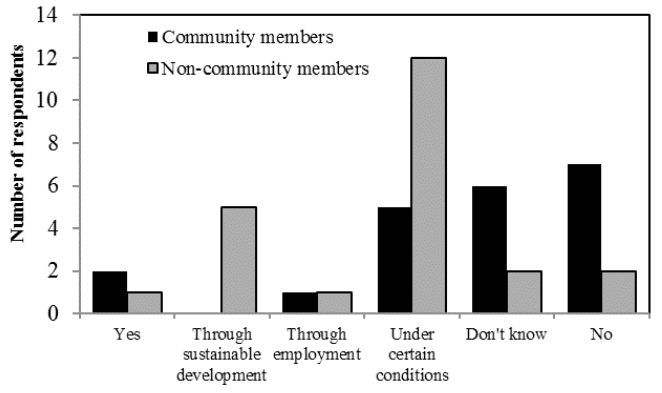

(c)

Community shares project revenue

Figure 4 Participant perspectives of forest carbon project benefits and revenue distribution. During interviews, some participants $(\mathrm{n}=25)$ described potential benefits from forest carbon projects in their region (a). Interview participants were asked if they thought local communities would share in project revenue (b). Respondents $(\mathrm{n}=41)$ were allowed to give multiple answers. Respondents who indicated certain conditions would be necessary to share revenue $(n=17)$ described those conditions (c).

gested a variety of possible roles, ranging from being informed and supportive of the project (8) to acting as the main stakeholder (6). Only 3 respondents, all community members, did not believe the community could play a role and 2 ( 1 community member, 1 non-community member) were unsure.

Interview participants described a multitude of possible benefits from forest carbon projects in the region (Figure 4), many of which would extend to local populations and forest administrative units. Benefits were divided almost evenly between social benefits and benefits to forest management and the local environment. Of the 25 participants who mentioned project benefits, 12 described additional employment or income and 11 described increased recreation and tourism opportunities. While the numbers of community members (13) and non-community members (12) mentioning benefits were almost equal, non-community members perceived over 1.5 times the number of benefits as community members and were the only ones to suggest money for forest management, sustainable development, and education or research as possible benefits. 
Participants were less certain communities would share financial revenue from projects (Figure 4). Only 3 participants (of 44) responded that communities would share project revenue. Eleven respondents did not believe revenue would reach communities and 8 did not know. More non-community members believed local communities would share revenue under certain conditions, while more community members were skeptical of receiving a share in revenue at all. Some respondents, mostly non-community members, believed the public would share project revenue through additional jobs or sustainable regional development, rather than through direct financial payments. Many responses indicated that project design, including responsibility for benefit distribution, would be a primary condition in determining whether and how communities would share financial benefits.

Seven participants raised the issue of corruption during interviews. Three participants (non-community member) speculated that revenue from carbon projects could be vulnerable to corrupt schemes, while three additional participants (community member and non-community member) implied the possibility of corruption, using phrases such as, "they would steal it all," "all money will go in one pocket," and "it will disappear." Interview respondents indicated that the risk of corruption in carbon projects could be reduced through greater transparency and a robust, enforceable contract.

\section{Discussion}

\section{Forest tenure and use}

Our finding that NTFPs are important to rural livelihoods in Ukraine is consistent with other studies (Stryamets et al. 2012); however, our results show that non-market experiential uses, such as recreation and spiritual values, are also essential to well-being in the region. The data show that local communities in the
Carpathian region are accustomed to open access to forests, which facilitates many of their common forest uses. However, without formal property rights to project lands, community members may not be considered primary project stakeholders, even if they utilize forest resources for subsistence needs (Corbera et al. 2007). Community members' close relationship to the forest and dependence on forest products indicates that they are indeed key project stakeholders and their needs and preferences should be considered during project design. Our results support the view that incorporating local community livelihood practices and needs, such as small-scale extraction, into project development can prevent potential conflicts (Blom et al. 2010). Several important forest products and uses, such as collection of herbaceous NTFPs and recreation, do not significantly affect forest carbon sequestration or storage (American Carbon Registry 2010) and could be permitted in a carbon project.

\section{Community participation and potential bene- fit distribution}

While some organizations, such as the NGO FORZA (Foellmi \& Schwitter 2009) and protected areas like the Carpathian Biosphere Reserve and Uzhansky National Nature Park, are trying to increase community participation in forest management in western Ukraine, our interview results indicate that public participation in forest management is still uncommon. Many community members do not believe the SFE fully informs them of forest management goals and activities, which may contribute to negative perceptions of SFE forest management. A similar lack of community involvement in carbon projects could lead to negative perceptions of project management. Local mistrust of project developers can arise when local participation is not incorporated into the decision-making process (Asquith et al. 2002). Community participation could allow local traditions and preferences to be voiced and agreements on fair cost and bene- 
fit arrangements to be formed between project designers and communities, increasing project transparency, decreasing community impacts, and perhaps strengthening stakeholder relationships. The experiences of Ukrainian forest initiatives that sought to engage local communities, such as FORZA and the protected areas mentioned above, could be useful in designing participatory mechanisms for carbon projects in Ukraine. Effective local participation in carbon project development and implementation may even prompt increased participation in other aspects of forest management decision-making and policy and expand to other locations.

While community members are skeptical of receiving direct financial payments from the sale of carbon, their anticipation of other benefits that improve the local social, economic, and ecological situation supports the view that direct financial payments are not the only way community members are willing to be compensated for impacts from forest carbon projects (Rosa et al. 2004). However, corruption, the use of fraudulent activity for personal gain, may be an important issue to consider in developing forest carbon projects in Ukraine. Weak governance, corruption, and rights abuses have arisen in some forest conservation schemes elsewhere in the world, such as financial mismanagement, missing bilateral funds, forest owners conned into selling their carbon rights, and perceptions of collusion between governments and carbon brokers (Hatcher \& Bailey 2011).

As indicated above, if communities are not considered important project stakeholders and are left out of project design and decision-making, there could be significant negative livelihood effects. In the case of fuelwood, a decline in availability could increase the potential for illegal harvesting and corruption. Although community members are accustomed to purchasing fuelwood and timber products, reports in our interviews of illegal harvesting in the region, corroborated by remote sensing re- search (Kuemmerle et al. 2009), suggest that a decrease in affordable supply of these products may lead some to harvest independently within the project area, putting the project's carbon mitigation goals at risk.

Comparing the distribution of potential forest carbon project costs and benefits in the Ukrainian Carpathians, we see that communities may experience negative livelihood effects, and prospects of compensatory project benefits are uncertain. Community participation in identification of important lands, as suggested by social and environmental standards (CCBA 2008, REDD+ SES 2010), could be useful in siting projects to minimize impacts and alleviate concerns of restricted access. To address the significant livelihood impact of a potential decrease in fuelwood availability, a fuelwood program could be created within the carbon project to ensure an affordable and accessible fuelwood supply. This could help ease concerns and cut the cost to communities, while also protecting the project's carbon mitigation goals. Transparency and accountability are important indicators for successful REDD+ projects, making trustworthiness between actors important (Pettenella \& Brotto 2012, Tacconi et al. 2013). Opportunistic behavior, such as corruption, may be more likely to be exposed and productivity increased when public and private sectors work together (Ostrom 1996). This suggests that a transparent process of designing and distributing benefits that includes effective community participation - a social and environmental standards guideline - may help combat perceived corruption and ensure equitable distribution.

\section{Conclusions}

Our data show that local communities in the Ukrainian Carpathian Mountain region are important forest-dependent stakeholders in conservation projects and require strong social safeguards. This is similar to the situation in 
developing economies, and indicates that lessons learned from projects in those regions can be informative to project development in Ukraine and possibly to other post-socialist, transitioning economies in Central and Eastern Europe. Using a social and environmental standard in combination with a carbon accounting standard during project design will increase the likelihood of fair cost and benefit distribution and credible carbon mitigation. Following these guidelines will help meet the expectations of community participation and benefit sharing expressed by our interview participants. Oversight of a robust carbon accounting standard with on-the-ground assessments carried out by international auditors is likely to not only ensure carbon goals, but also increase project transparency. Although conforming to two standards may be less cost-effective, such a combination could increase a project's competitiveness on the market (Diaz et al. 2011).

While post-socialist, transitional economies differ as a group from tropical developing countries, there are differences within the group that need to be considered. Differing stages of economic liberalization and varying histories of nationalization and land restitution policies result in unique economic and sociopolitical conditions that may affect the structure of forest tenure, the forest industry, and level of social capital. While this paper provides insights that are valuable for the broader region, it is based upon a limited dataset of key informant interviews and observations in western Ukraine. Further research on community impacts and engagement in projects in other post-socialist, transitional economies will strengthen our understanding and assist future development of equitable and successful forest carbon projects.

\section{Acknowledgements}

This work was funded by the United States Fulbright Program, the Trust for Mutual Un- derstanding, the European Forest Institute, and the University of Vermont (UVM). We are grateful to the Ukrainian National Forestry University, the Agency for Sustainable Development of the Carpathian Region "FORZA", the Carpathian Biosphere Reserve, the Ukrainian University of Life Sciences and Agriculture, the Geomatics Laboratory at Humboldt University of Berlin, and UVM's Institute for Environmental Diplomacy and Security for ongoing collaboration, and to Oleh Chaskovskyy for contributing the map. We would like to thank our research participants, as well as Vitaliy M., Olha H., Vasyl P., Sofia M., Yuriy Sh., Victoria S.-G., Nataliya V., Vitaliy S., Ivanna K., Yurij Bihun, Marta Ceroni, Sergiy Zibtsev, and Dmytro Karabchuk for their valuable assistance.

\section{References}

Amato, A.J., 1998. In the wild mountains: Idiom, economy, and ideology among the Hutsuls, 1849 to 1939. Doctor of Philosophy Doctoral dissertation, Department of History, Indiana University, Bloomington, 411 p.

American Carbon Registry, 2010. The American carbon registry forest carbon project standard. Winrock International, Arlington, $70 \mathrm{p}$.

Asquith, N.M., Vargos Rio, M.T., Smith, J., 2002. Can forest-protection carbon projects improve rural livelihoods? Analysis of the Noel Kempff Mercado Climate Action Project, Bolivia. Mitigation \& Adaptation Strategies for Global Change 7: 323-337. DOI: 10.1023/A:1024712424319

Blom, B., Sunderland, T., Murdiyarso, D., 2010. Getting REDD to work locally: Lessons learned from integrated conservation and development projects. Environmental Science \& Policy 13: 164-172. DOI: $10.1016 /$ j.envsci.2010.01.002

Bray, D.B., Duran, E., Ramos, V.H., Mas, J., Velazquez, A., McNab, R.B., Barry, D., Radachowsky, J., 2008. Tropical deforestation, community forests, and protected areas in the Maya forest. Ecology and Society 13(2): 56. DOI: 10.5751/ES-02593-130256

Brown, K., Corbera, E., 2003. Exploring equity and sustainable development in the new carbon economy. Climate Policy 3S1: S41-S56.

CCBA, 2008. Climate, community \& biodiversity project design standards second edition. CCBA, Arlington, 50 p.

Corbera, E., Brown, K., 2010. Offsetting benefits? Analyz- 
ing access to forest carbon. Environment and Planning A 42(7): 1739-1761. DOI: 10.1068/a42437

Corbera, E., Kosoy, N., Martínez Tuna, M., 2007. Equity implications of marketing ecosystem services in protected areas and rural communities: Case studies from Meso-America. Global Environmental Change 17(3-4): 365-380. DOI: 10.1016/j.gloenvcha.2006.12.005

Diaz, D., Hamilton, K., Johnson, E., 2011. State of the forest carbon markets 2011: From canopy to currency. Ecosystem Marketplace, Washington, D.C., 70 p.

Elbakidze, M., Angelstam, P., 2007. Implementing sustainable forest management in Ukraine's Carpathian Mountains: The role of traditional village systems. Forest Ecology and Management 249(1-2): 28-38. DOI: 10.1016/j.foreco.2007.04.003

Foellmi, H., Schwitter, R., 2009. Forest resource planning for people - with people: Two-level planning for sustainable natural resource managment. In: Soloviy, I.P, Keeton, W.S. (eds.), Ecological economics and sustainable forest management: Developing a trans-disciplinary approach for the Carpathian Mountains. Ukrainian National Forestry University Press, Lviv, pp. 275-288.

Gibson, C.C., Williams, J.T., Ostrom, E., 2005. Local enforcement and better forests. World Development 33(2): 273-284. DOI: 10.1016/j.worlddev.2004.07.013

Goldstein, A., Gonzalez, G., 2014. Turning over a new leaf: State of the forest carbon markets 2014. In: Peters-Stanley, M. (ed.), Ecosystem Marketplace, Washington, D.C., 87 p.

Hamrick, K., Goldstein, A., 2016. Raising ambition: State of the voluntary carbon markets 2016. Ecosystem Marketplace, Washington, D.C., 50 p.

Hatcher, J., Bailey, L., 2011. Governance in the world's tropical forests: Where will REDD+ land? In Transparency International (ed.), Global corruption report: Climate change. Earthscan, London, pp. 315-326.

Irland, L.C., Kremenetska, E., 2009. Practical economics of forest ecosystem management: The case of the Ukrainian Carpathians. In Soloviy, I.P, Keeton, W.S. (eds.), Ecological economics and sustainable forest management: Developing a trans-disciplinary approach for the Carpathian Mountains. Ukrainian National Forestry University Press, Lviv, pp. 180-200.

Kaufmann, D., Kraay, A., Mastruzzi, M., 2014. Worldwide governance indicators: Country data report for Ukraine, 1996-2013. World Bank, Washington, D.C., 7 p.

Keeton, W.S., Angelstam, P., Baumflek, M., Bihun, Y., Chernyavskyy, M., Crow, S.M., Deyneka, A., Elbakidze, M., Farley, J., Kovalyshyn, V., Mahura, B., Myklush, S., Nunery, J.R., Soloviy, I.P., Zahvoyska, L., 2013. Sustainable forest management alternatives for the Carpathian Mountain region, with a focus on Ukraine. In: Kozak, J., Ostapowicz, K., Bytnerowicz, A., Wyzga, B. (eds.) The Carpathians: Integrating nature and society towards sustainability. Springer-Verlag, Berlin and Heidelberg, pp. 331-352. DOI: 10.1007/9783-642-12725-0_24
Kerchner, C.D., Keeton, W.S., 2015. California's regulatory forest carbon market: Viability for northeast landowners. Forest Policy and Economics 50: 70-81. DOI: 10.1016/j.forpol.2014.09.005

Kollmuss, A., Zink, H., Polycarp, C., 2008. Making sense of the voluntary carbon market: A comparison of carbon offset standards. WWF Germany, Berlin, 105 p.

Kuemmerle, T., Chaskovskyy, O., Knorn, J., Radeloff, V.C., Kruhlov, I., Keeton, W.S., Hostert, P., 2009. Forest cover change and illegal logging in the Ukrainian Carpathians in the transition period from 1988 to 2007. Remote Sensing of Environment 113(6): 1194-1207. DOI: $10.1016 /$ j.rse.2009.02.006

Kuemmerle, T., Olofsson, P., Chaskovskyy, O., Baumann, M., Ostapowicz, K., Woodcock, C.E., Houghton, R.A., Hostert, P., Keeton, W.S., Radeloff, V.C., 2011. Post-Soviet farmland abandonment, forest recovery, and carbon sequestration in western Ukraine. Global Change Biology 17(3): 1335-1349. DOI: 10.1111/j.13652486.2010.02333.x

Larson, A.M., Barry, D., Dahal, G.R., 2010. New rights for forest-based communities? Understanding processes of forest tenure reform. International Forestry Review 12(1): 78-96. DOI: 10.1505/ifor.12.1.78

Lincoln, Y.S., Guba, E.G., 1985. Naturalistic inquiry. SAGE Publications, Inc., Newbury Park, CA, 416 p.

Marshall, C., Rossman, G.B., 2011. Designing Qualitative Research, 5th ed. SAGE Publications, Inc., Washington, D.C., 321 p.

Nordberg, M., 2007. Ukraine reforms in forestry 19902000. Forest Policy and Economics 9: 713-729. DOI: 10.1016/j.forpol.2006.07.002

Olander, L.P., Galik, C.S., Kissinger, G.A., 2012. Operationalizing REDD+: Scope of reduced emissions from deforestation and forest degradation. Current Opinion in Environmental Sustainability 4: 661-669. DOI: 10.1016/j.cosust.2012.07.003

Ostrom, E., 1996. Crossing the great divide: Coproduction, synergy, and development. World Development 24(6): 1073-1087. DOI: 10.1016/0305-750X(96)00023-X

Pagiola, S., Landell-Mills, N., Bishop, J., 2002. Making market-based mechanisms work for forests and people. In Pagiola, S., Bishop, J., Landell-Mills, N. (eds.), Selling forest environmental services: Market-based mechanisms for conservation and development. Earthscan, London, pp. 261-289.

Pettenella, D., Brotto, L., 2012. Governance features for successful REDD+ projects organization. Forest Policy and Economics 18: 46-52. DOI: 10.1016/j.forpol.2011.09.006

REDD+ SES., 2010. REDD+ social \& environmental standards. REDD+ SES, Washington, D.C., 16 p.

Rodríguez de Francisco, J.C., Budds, J., Boelens, R., 2013. Payment for environmental services and unequal resource control in Pimampiro, Ecuador. Society \& Natural Resources 26(10): 1217-1233. DOI: 10.1080/08941920.2013.825037

Rosa, H., Kandel, S., Dimas, L., 2004. Compensation for 
environmental services and rural communities: Lessons from the Americas. International Forestry Review 6(2): 187-194. DOI: 10.1505/ifor.6.2.187.38401

Sikor, T., 2003. The commons in transition: Agrarian and environmental change in Central and Eastern Europe. Environmental Management 34(2): 270-280. DOI: 10.1007/s00267-003-3007-5

Smith, J., Scherr, S.J., 2003. Capturing the value of forest carbon for local livelihoods. World Development 31(12): 2143-2160. DOI: 10.1016/j.worlddev.2003.06.011

Soloviy, I.P., Cubbage, F.W., 2007. Forest policy in aroused society: Ukrainian post-Orange Revolution challenges. Forest Policy and Economics 10(1-2): 6069. DOI: 10.1016/j.forpol.2007.05.003

Strochinskii, A.A., Pozyvailo, Y.M., Jungst, S.E., 2001. Forests and forestry in Ukraine: Standing on the brink of a market economy. Journal of Forestry (August): 34-
38.

Stryamets, N., Elbakidze, M., Angelstam, P., 2012. Role of non-wood forest products for local livelihoods in countries with transition and market economy: Case studies in Ukraine and Sweden. Scandinavian Journal of Forest Research 27: 74-87. DOI: 10.1080/02827581.2011.629622

Tacconi, L., Mahanty, S., Suich, H., 2013. The livelihood impacts of payments for environmental services and implications for REDD+. Society \& Natural Resources 26(6): 733-744. DOI: 10.1080/08941920.2012.724151

Transparency International., 2014. Corruption perceptions index 2014. Transparency International, Berlin, 9 p.

Zbinden, S., Lee, D.R., 2005. Paying for environmental services: An analysis of participation in Costa Rica's PSA program. World Development 33(2): 255-272. DOI: $10.1016 /$ j.worlddev.2004.07.012 